ORNL/TM-2012/583

\title{
Closed Cell Foam Insulation: A Review of Long Term Thermal Performance Research
}

\section{November 2012}

Prepared by

Therese Stovall

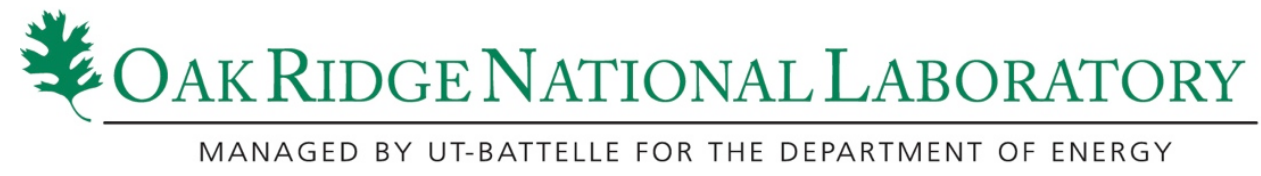




\section{Introduction}

Research related to closed-cell foam insulation dates back to the 1960s [Cuddihy and Moacanin, 1967; Norton, 1967]. This form of insulation is often more costly than other products, but offers relatively high thermal resistance and intrinsic strength properties. This report will focus on the thermal performance of the products. The specific goals of this project are to:

- Summarize the existing literature on thermal performance of closed cell plastics over the last thirty years.

- Review the science of closed cell plastic foam aging and how test methods have been developed to attempt to address this reality.

- Review the models that are available to predict the long-term performance of closed cell plastic foams.

As with other insulation products, closed-cell foam is designed to retard heat transfer. Convective heat transport is essentially eliminated by the small cell size. In a few specialty products, the cell size is small enough to inhibit gaseous conduction as well, but more often gases with low thermal conductivity are selected to reduce gaseous conduction within the closed cells. These gases are also used to produce the fine cellular structure of closed-cell foam and are called blowing agents. In closed-cell foam insulation, these gases remain within the cells for a long period of time and are of particular interest for two reasons. First, the gases initially selected were found to have an adverse effect on the global environment. This led to the development of multiple generations of products as those gases were transitioned to more benign blowing agents. Second, the gaseous content within the insulation changes over time, which causes the thermal performance of the product to also vary over time, or 'age'.

This paper will review the research that has improved our understanding of the long-term thermal performance of closed cell foam insulation, summarize the science of foam aging, and describe some models that have been developed over the years to investigate the phenomena. An annotated bibliography is included in Appendix A. Standards pertinent to foam insulation performance and aging are summarized in Appendix B.

\section{The Physics of Heat Transport Through Closed-Cell Foam Insulation} [Glicksman 1994]

The most comprehensive resource for an in-depth description of foam insulation thermal performance, and the source for the discussion in this section, is Glicksman, 1994. Total heat transport through foam insulation is typically represented as the superposition of the heat transported via solid conduction, gas conduction, and radiation, as shown in Eq. 1. This approximation is valid for low-density materials with modest temperature differences.

$$
q_{\text {total }}=\left(q_{\text {gas }}+q_{\text {solid }}\right)_{\text {conduction }}+q_{\text {radiation }} \quad \text { Eq. } 1
$$

where:

$$
\mathrm{q}=\text { heat transfer, } \mathrm{W} / \mathrm{m}^{2} \text {. }
$$


The solid conductive portion is approximately linear with foam density, ranging from less than $5 \%$ to more than $40 \%$ as foam ranges from 10 to $80 \mathrm{~kg} / \mathrm{m}^{3}$. The gas conductivity depends upon the gas mixture within the cells. In new foam, the gas contributes from $\sim 40 \%$ for foams filled with low-conductivity blowing agents; up to $\sim 70 \%$ for foams filled with air. The radiation portion of the heat transfer decreases rapidly as density increases from 5 to $20 \mathrm{~kg} / \mathrm{m}^{3}$ and more slowly for further increases in density. The foam density is therefore an optimized trade-off between radiation and solid conduction heat transport mechanisms. For CFC-11-filled polyurethane foam, the decreasing radiation heat transfer equals the increasing solid conduction at a density of $\sim 40 \mathrm{~kg} / \mathrm{m}^{3}$.

The solid conduction and radiation performance are determined by the foam morphology, which does not change appreciably over the lifetime of the product. The magnitude of the solid conduction in low density foam is [Glicksman, 1994, page 121] shown in Eq. 2.

$$
q_{\text {solid conduction }}=-k_{p} \frac{(1-\text { Void fraction })}{3}\left[f_{s}\left(\frac{a}{b}\right)^{0.5}+2\left(1-f_{s}\right)\left(\frac{a}{b}\right)^{0.25}\right] \frac{d T}{d x} \quad \text { Eq. } 2
$$

where:

$$
\begin{array}{lll}
\mathrm{k}_{\mathrm{p}} & = & \text { cell wall and strut (polymer) thermal conductivity, } \\
\mathrm{f}_{\mathrm{s}} & = & \text { fraction of solid in strut, } \\
\mathrm{a} / \mathrm{b} & = & \text { cell aspect ratio, and } \\
\mathrm{dT} / \mathrm{dx} & = & \text { temperature gradient. }
\end{array}
$$

The major factor in the net radiation flux is the emission from the solid portions of the foam. The radiation heat transfer is usually modeled using the Rosseland equation, which is valid where the radiation mean free path is much less than the foam thickness and the foam is isotropic (that is, the cell aspect ratio is one). The extinction coefficient is the reciprocal of the photon mean free path. Reducing the mean free path of the photons, by reducing the cell size, is therefore an effective way to reduce this portion of the total heat transport, as shown in Eqs. 3 and 4. The radiation transmission from one side of the foam to the other is very small, so that using reflective layers on the exterior foam surfaces has little impact on the radiation heat transport.

$$
\begin{gathered}
q_{\text {radiation }}=-\left[\frac{16}{3\left(\mathrm{~K}_{\mathrm{e}}\right)}\right] \sigma T^{3} \frac{d T}{d x} \\
K_{e}=\frac{4.10}{d}\left(f_{s} \frac{\rho_{f}}{\rho_{s}}\right)^{0.5}+\left(1-f_{s}\right)\left(\frac{\rho_{f}}{\rho_{s}}\right) K_{\mathrm{e}, \text { cell walls }}
\end{gathered}
$$

where:

$$
\begin{array}{lll}
\mathrm{K}_{\mathrm{e}} & = & \text { Extinction coefficient } \\
\sigma & = & \text { Stefan-Boltzman constant } \\
\mathrm{T} & = & \text { absolute temperature } \\
\mathrm{d} & = & \text { cell diameter, } \\
\rho_{\mathrm{f}} / \rho_{\mathrm{s}} & = & \text { ratio of foam density to solid polymer density, and } \\
\mathrm{d} & = & \text { cell diameter. }
\end{array}
$$

The remainder of the total conduction is due to gaseous conduction. As gases diffuse in and out of the foam, that mixture changes, and therefore the total thermal conductivity changes. The thermal conductivity of a gas mixture has been characterized by Wassiljewa and Lindsay and 
Bromley as function of mole fraction, thermal conductivity, viscosity, and absolute boiling temperature at one atmosphere pressure, as shown in Eq. 5 [Wassiljewa, 1904; Lindsay and Bromley, 1950]. This form reflects the interactions between gas molecules as explained by Glicksman, 1994, "The conductivity is a function of the mean free path; the mean free path of a gas component will be altered when a second component is present. For example, nitrogen in the presence of a high molecular weight blowing agent will have reduced contribution to the conductivity because the larger molecules will inhibit the motion of the smaller nitrogen molecules."

$$
q_{\text {gas conduction }}=-\sum_{i=1}^{N} \frac{y_{i} k_{g i}}{\sum_{j=1}^{N} \frac{y_{i}}{4}\left(\left\{1+\left(\frac{\mu_{i}}{\mu_{k}}\left(\frac{M_{j}}{M_{i}}\right)^{0.75} \frac{\left(1+1.5 C_{0} \frac{\sqrt{T_{b i} T_{b j}}}{T}\right)}{\left(1+1.5 \frac{T_{b j}}{T}\right)}\right)^{0.5}\right\}^{2}\left\{\frac{\left(1+1.5 C_{0} \frac{\sqrt{T_{b i} T_{b j}}}{T}\right)}{\left(1+1.5 \frac{T_{b i}}{T}\right)}\right\}\right)} \frac{d T}{d x}
$$

where:

$$
\begin{array}{lll}
\mathrm{N} & = & \text { Number of gas species, } \\
\mathrm{y}_{\mathrm{i}} & = & \text { Mole fraction of } \mathrm{i}^{\text {th }} \text { component, } \\
\mathrm{k}_{\mathrm{gi}} & = & \text { Thermal conductivity of pure } \mathrm{i}^{\text {th }} \text { component, } \\
\mu & = & \text { Viscosity of pure } \mathrm{i}^{\text {th }} \text { component, } \\
\mathrm{M} & = & \text { Molecular weight, } \\
\mathrm{C}_{0} & = & 1.0 \text { unless one of the } \mathrm{i} \text { or } \mathrm{j} \text { gases is polar (such as water), and } \\
\mathrm{T}_{\mathrm{bi}} & = & \text { Absolute boiling temperature at one atmosphere pressure of pure } \mathrm{i}^{\text {th }}
\end{array}
$$

The radiation and gas conduction are both dependent upon the local temperature and will therefore vary throughout the thickness of the foam. Even more important, the gas mixture will vary throughout the thickness of the foam during the diffusion, or aging, process, causing variations in the gas conduction per Eq. 5.

As with any air-filled insulation, the thermal conductivity is temperature dependent, decreasing with temperature. Depending on the selected blowing agent, condensation may occur within the cell volume at lower temperatures. Most research has shown that the addition of this small amount of liquid to the cell walls has a negligible effect on the solid conduction portion of the heat transfer [Bogdan, Hoerter, and Moore. 2005, Kumaran et al. 1989]. However, if any portion of the cell gas contents condenses, the partial pressure (and mole fraction) for that gas will decrease, impacting the thermal conductivity of the gas mixture. The reduced pressure of the low thermal conductivity gas in the mixture causes an increase in the gas conductivity, which continues as the temperature drops until all the blowing agent throughout the foam thickness has condensed. At that point, the thermal conductivity will again decrease with decreasing temperatures.

In closed-cell foam, the radiation and conduction heat transfer mechanisms are coupled, with cell walls largely transparent to radiation and cell struts largely opaque to radiation. This is a second 
order effect, so that for most purposes they can be treated as independent mechanisms. However, this coupled mode of heat transfer makes the measured effective thermal conductivity sensitive to the total thickness of the foam and the emissivity of the testing apparatus surfaces. Below a certain threshold, the foam is 'optically thin', interacting with the surfaces of the thermal conductivity measurement device. In that regime, the measured effective thermal conductivity will vary with foam thickness. Outside that regime, the foam is 'optically thick', and the measured effective thermal conductivity no longer varies with thickness. This characteristic is an important consideration in the thin-slicing accelerated aging method described below. The optically thick regime where radiation can be modeled as a diffusion process should start $\sim 10$ $\mathrm{mm}$ for most polyurethane foams [Glicksman, 1994].

\section{The Science of Foam Aging [Hoogendoorn 1994]}

The most comprehensive resource for an in-depth description of foam insulation aging, and the source for the discussion in this section, is Hoogendoorn, 1994. The foam aging is caused by the diffusion of atmospheric gases into the foam and the diffusion of blowing agent gases out of the foam. The process can be broken down into several stages. First, the gas within a cell dissolves into the cell wall or strut material. Second, the gas is transported across the thickness of the cell wall or strut. Third, the gas is released into the bounding space, either an adjacent cell or the open surrounding environment. Thicker cell walls and struts retard the diffusion process, but increase the solid conduction heat transfer; so again, the foam design is based on an optimal compromise between these factors.

Research has generally agreed that this three-step process within homogenous foam can be described with an effective diffusion resistance, as described by Fick's Law and shown in Eq. 2. Within any given foam, the diffusion resistance for each gas is a unique function of the material and the temperature. That is, while elevated temperatures will reduce the diffusion resistance for all gases, the amount of reduction will be different for each gas. Also, for both modeling and accelerated aging purposes, modifications are often made to consider differences in diffusion parameters at regions at or near the surface vs. within the core of the foam.

$$
\frac{\partial c}{\partial t}=D_{e f f} \frac{\partial^{2} c}{\partial x^{2}} \quad \text { Eq. } 6
$$

Where:

$$
\begin{array}{lll}
\mathrm{c} & = & \text { gas concentration as a function of time, } \\
\mathrm{t} & = & \text { time, and } \\
\mathrm{D}_{\text {eff }}= & \text { effective diffusion coefficient. }
\end{array}
$$

Note the diffusion process is driven by the gradient in the partial pressure for each gas, independent of other gases present. The blowing agent gases are selected based upon their characteristics of low thermal conductivity and slow diffusion rates through the foam polymers. The atmospheric gases have a greater thermal conductivity and are typically much smaller molecules with much faster diffusion rates through the foam. The impact of this inward atmospheric gas diffusion is the early steeper portion of the aging curve shown in Fig. 1. Over a longer period of time, the blowing agent diffuses out of the foam, increasing the mixed gas thermal conductivity still further but at a much slower rate. 


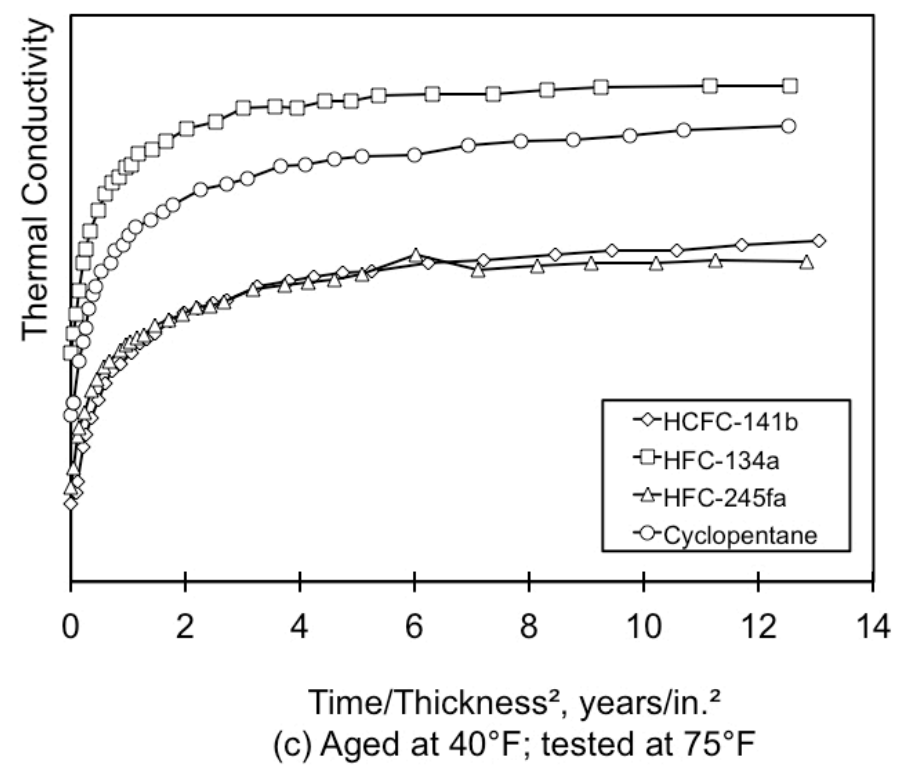

Figure 1 Typical aging curves, data from prototype specimens in [Wilkes et al. 2003]

In addition to work on accelerated aging, much research has focused on full product thickness aging[Desjarlais, 1984; Mukhopadhyaya, et al. 2010; Wilkes, et al., 2003; Bomberg and Alumbaugh, 1993; Desjarlais, Christian, and Graves, 1993; Kabayama, 1987; Yarbrough, Graves, and Christian, 1991]. One of the more important results of this work is that nonpermeable facers, such as foil, are often less effective than expected. The bonding between these facers and the foam body is often flawed, providing an open pathway for gas exchanges[Glicksman 1994b].

\section{Accelerating Foam Aging}

As discussed, foam aging takes place over a long time frame. For thick foams with large molecule blowing agents, the aging could take more than 50 years! Accelerating the aging process is desirable, then, for several reasons. First, rated values are used to make product comparisons; it is useful if the rated values therefore reflect the long term performance of each product. Second, designers need to have long term performance information when balancing out expected heat transfer for buildings or appliances against the size of the equipment needed to heat or cool those spaces over their lifetime. Third, evaluating possible product improvements, such as the transition from CFC blowing agents to less harmful gases, needs to be made based on the product's long term performance. Overall, the accelerated aging research has focused on (1) elevated temperature to increase diffusion rates, (2) thin slicing to reduce diffusion lengths, and (3) evaluating diffusion parameters to facilitate models.

\subsection{Elevated temperature age acceleration}

The elevated temperature work is interesting because the same experimental results led to two starkly different conclusions, depending upon which side of the Atlantic Ocean the researcher called home. The experimental work clearly showed, for CFC blowing agents used in the 1980's, that a limited time at elevated temperature would effectively complete the inward diffusion of atmospheric gases while having a minimal impact upon the outward diffusion of the blowing 
agents. (In fact, the diffusion rates for the CFCs were more than an order of magnitude less than those for atmospheric gases.) For example, Bomberg and Gilbo exposed foam insulation specimens to varying temperatures for varying periods of time. They found that after two years, the foam thermal performance was not affected by this treatment because for all cases the inward diffusion of atmospheric gases was complete but the outward diffusion of blowing agent was relatively unchanged [Bomberg and Gilbo 1989]. Hoogendoorn notes that elevated temperature aging provides a better representation of long term performance for those foams with the slowest-diffusing blowing agents [Hoogendoorn 1994].

On the European side of the Atlantic, this elevated temperature age acceleration was considered adequate to characterize the long-term thermal performance, based on the observation that a large part of the blowing agent would remain trapped within the foam cells throughout the service life for that product. On the North American side of the Atlantic, elevated temperature age acceleration was considered inadequate because it failed to quantify the amount of blowing agent that would diffuse out of the foam during the service life. This dichotomy led to the inclusion of elevated temperature procedures for foam ratings in Europe and the development of thin-slicing test methods in Canada and the U.S. The European standards have been based on a number of studies, some of which included 15 years of full thickness foam aging. [BING, 2006; Isberg, 1988] In most of these European standards, correction factors are applied to account for the long term blowing agent gas diffusion not captured in the elevated temperature measurement.[ ACERMI; Annex C in multiple EN standards as shown in Appendix B]. Pending the completion of the thin-slicing research, Canada and the U.S. also allowed ratings based upon specified times at elevated temperatures or six months of room temperature aging, producing values similar to those used in Europe. In North America, correction factors were not used, but the process was seen to provide consistent ratings, even though it was a poor representation of long-term performance.

The differences between elevated temperature and thin-slicing acceleration methods are greater with modern blowing agents than with the CFC generation of gases, because the diffusion rates for air and blowing agent gases are not as far apart as they once were. The correction factors in European standards include several qualifying options based on the observed rate of aging.

\subsection{Thin slicing age acceleration}

As shown in Eq. 2, the rate of gas diffusion is inversely proportional to the square of the foam thickness. Thin slicing therefore accelerates the gas diffusion for all species proportional to the square of the ratio of the product thickness to the slice thickness, as shown in Eq. 7. For example, if the slice is one fourth as thick as the foam product, then one year of slice aging will result in the same total gas diffusion as 16 years for the full thickness product [ASTM C1303, CAN/ULC S770].

$$
\text { Time }_{\text {thin slice aging }}=\text { Time }_{\text {full product thickness aging }}\left(\frac{\text { thickness }_{\text {thin slice }}}{\text { thickness }_{\text {product }}}\right)^{2}
$$

As with any test method, the devil is in the details. The important factors for thin slicing acceleration are:

- Thickness of the destroyed surface layers (TDSL)

- Homogeneity and therefore the slice extraction location from the foam thickness profile 
- Slicing mechanism - slice flatness - slice uniformity

- Accuracy of thermal conductivity measurement device

Jan Isberg and Per Sandberg led early European research in this area [Isberg 1988, Sandberg and Isberg 1989, and Sandberg 1990]. This research covered all the major factors addressed during research that would continue to be of interest to researchers from 1988 to 2012, except for the influence of blowing agents not in use at that time. They recognized the importance of including surface slices for XPS products and the need for an adequate number of slices in the thermal conductivity measurement. Their research concluded with a practical proposal to use a single set of measurements taken at 90 days for a set of $10 \mathrm{~mm}$ slices representing the whole profile, or cross section, of the insulation product. Using empirical data as well as theoretical analysis, they concluded that this would provide 25 -year aged thermal conductivity values accurate to $+-5 \%$ for PUR $\left(\mathrm{CFCl}_{3}\right)$ of $20-200 \mathrm{~mm}$ thickness and for XPS $\left(\mathrm{CF}_{2} \mathrm{Cl}_{2}\right)$ of $50-200 \mathrm{~mm}$ thickness $(30 \mathrm{~mm}$ if the surface skin is retained).

Bomberg and Kumaran led most of the Canadian research, and have provided most of the research relevant to spray foam products [multiple references from Bomberg and Kumaran, with varying coauthors, from 1988 to 1994. Also see Yuan, 2010 re spray foam] In the U.S., the early research was largely led by Glicksman at the Massachusetts Institute of Technology (MIT) and Booth at Dow Chemical, with supporting work at Oak Ridge National Laboratory[see references from Glicksman, Booth, McElroy, Graves, and Wilkes]. The early work on foam thin-slicing coincided with great improvements in the accuracy and convenience of thermal conductivity measurement devices, and much of the research on foam performance was intertwined with this development [McElroy et al., 1991; Graves et al., 1991].

The work on thin slicing during the development of the ASTM C1303 standard test method focused on the integrated lifetime performance, usually over a period of 15 years. However, multiple researchers have noted that the instantaneous value after 5 years is approximately equal to that average[Stovall, 2009; Singh and Coleman, 2007]. The latest prescriptive version of C1303 therefore uses this equivalence, as does the ULC/CAN-S770 test method.

In any closed-cell product there will be some finite, albeit small, fraction of open cell walls. However, when foam is sliced, all the cells at the cut line are immediately open to the environment. This portion of the foam thickness is therefore immediately full of atmospheric gases and devoid of low-conductivity blowing agents. This introduces errors in the calculated time for the thermal conductivity measurement as well as in that thermal conductivity itself. Much research has shown that this error source will be less than 5\% if the total slice thickness is on the order of $10 \mathrm{~mm}$ or more[Fabian, et al., 1997; Stovall, 2006; Schwartz, Bomberg, and Kumaran, 1990; Booth and Grimes, 1993]. A recent ruggedness test for ASTM test method C1303 quantified the combined magnitude of the TDSL errors in the $\sim 1-3 \%$ range [Stovall 2012; ASTM 2012].

Many of the references listed in Appendix A include direct comparisons between field- and laboratory-aged full thickness specimens and thin slice aging predictions, lending a high degree of confidence in this test method [Christian et al, 1993; Stovall, Vanderlan, and Atchley, 2012; Mukhopadhyaya, et al., 2010; Bomberg, 1993; Booth, 1993]. 


\subsection{Measuring diffusion rates to facilitate models}

Early researchers noted that the diffusion rates for gases entering the cells are much faster than the rates for the blowing agent gases leaving the cells, and divided the aging curve into two distinct regions [Booth 1991; Graves et al., 1995; McElroy et al., 1991]. However, the diffusion phenomena for all gases are continuous over the entire time period, frustrating their efforts to use the slopes of the two regions to accurately measure diffusion rates. Diffusion rates can be more successfully measured using gravimetric and gas analysis equipment [Glicksman, Ostrogorsky and Chiapetta, 1984; Bhattacharjee et al., 1994; Singh, Ntiru, and Dedecker, 2003; Shankland, $1990]$.

\section{Modeling Capabilities}

Models have been used extensively to expand our understanding of foam insulation performance. When model predictions match closely with experimental measurements, they provide assurance in our understanding of the combined physical phenomena. For example, both full thickness and thin slice aging data has confirmed our use of effective diffusion coefficients for homogenous materials [Glicksman 1994 and many others in Appendix A]. Other times, failure to match experimental measurements is also revealing. For example, results from models of foam with barrier surfaces did not match experimental data. This lead researchers to examine why the barriers were not as effective as expected, and to develop new test methods to quantify that effect [Glicksman 1994b].

Most of the models discussed here have been developed as a part of a specific research program and are only available to fellow researchers within that organization. One exception would be the generic thermal conductivity codes that can be used to calculate gas diffusion via the analogy between heat and mass transfer.

As discussed above, the radiation and solid conduction within foam insulation are relatively unchanged over time and are typically modeled using the heat transfer relationships described above and in [Glicksman 1994]. The gas conduction is a function of the gas mixture within the foam, which is variable both in time and space. The gas diffusion, typically modeled using Fick's Law as described above, must therefore be calculated separately for each gas species.

The Distributed Parameter Continuum (DIPAC) model was developed by the Institute for Research in Construction/National Research Council of Canada (IRC/NRC). This work reflects the fundamental physics, including temperature-dependent diffusion coefficients, and has been successfully compared to experimental data [Bomberg and Kumaran 1994]. This model requires input of over 25 parameters with separate information for the core and surface layers, including density, initial blowing agent fraction and polymer index for each blowing agent, and effective diffusion coefficients at two temperatures for $\mathrm{N}_{2}, \mathrm{O}_{2}$, and each of the blowing agents [Bomberg 1988]. Later work, focused on evaluating surface barriers, benchmarked the 2-D form of the DIPAC model against experimental data. This project was only able to get agreement by tweaking a lateral diffusion parameter, but there were questions regarding experimental factors in that work [Mukhopadhyaya et al. 2004].

The Effective Conductivity Versus Age (ECVA) code was developed at the Massachusetts Institute of Technology (MIT). This tool uses measured foam diffusion coefficients and a numerical solution for foam aging, and was benchmarked against full thickness aging out to 
about two years. This work showed that most foam surface barriers have little effect on aging, and emphasized the advantages of thin slicing over elevated temperature acceleration methods [Ostrogorsky and Glicksman 1985 and 1986, Ostrogorsky 1987].

The early numerical models ran on computers that were much more limited than those available in 2012. One area of research focused on getting the results more efficiently by using the difference in time constants for gas diffusion vs. thermal conductance to accelerate the convergence of a finite difference model [Wang and Hagentoft, 1998 and 1999]. Other work used implicit methods to improve convergence, comparing a standard analytical solution for a single gas to the results of their numerical procedure before producing multi-gas results [Kondapi, Booth and Yarbrough, 1999].

The Dow Thermal Performance Prediction Model used a semi-empirical approach. It was employed to provide a quality assurance tool using physical measurements that could be made immediately after foam manufacture. This model was also benchmarked against full-thickness measured data for CFC-12 blown foams [Booth. 1993].

The gas diffusion is a mass transfer process analogous to heat transfer in a homogenous specimen. Many of the models used to predict the localized time-variant gas contents are based on similar finite difference or finite element heat transfer models. One such model, Heating 7, was used directly to model the partial pressure for each gas specie in split pipe insulation, where the gas diffusion is much more complex than in the more typically modeled slab geometry (see Fig. 2) [Childs 1993].

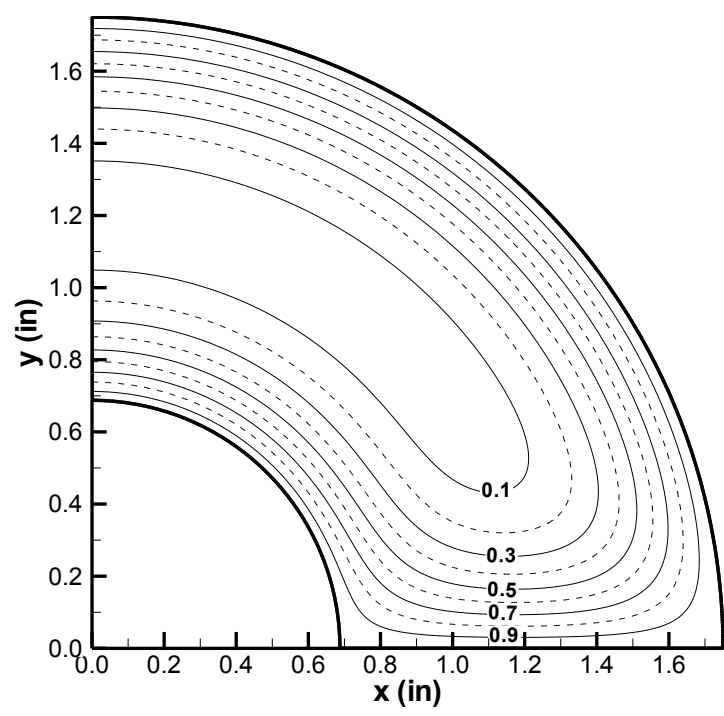

Figure 2 Application of Heating 7 finite difference for 3-D gas diffusion in split pipe insulation showing ingress of nitrogen during initial aging (contours show the ratio of local partial pressure to atmospheric pressure), work by Ken Childs given to this author from work described in [Wilkes, et al., 2002]

Other models have been more complex, looking at a two-zone approach to account for differences in the diffusion coefficients near densified or adhered surfaces. One such model, 
AgeSim, was developed at Huntsman Polyurethanes and was first validated against measured data for the core foam region. An effective diffusion coefficient for each gas was separately obtained by cell gas analysis and used as input to the model. AgeSim then combined the validated methodology with empirical results to assign a "Calibrated skin factor" from elevated temperature aging data iterated through the model [Singh, Ntiru, and Dedecker 2002 and 2003, Singh and Coleman 2007]. Such 'tweaking' factors can be found in many models, and are useful so long as the adjustments are based upon a thorough understanding of the physical process.

During the development of the ASTM C1303 test method, a series representation of the exact solution for simple geometries using Fick's Law was programed and applied to a two-zone representation of surface and core thin slices. A parametric examination of possible relationships between the diffusion coefficients in the two regions was explored, but did not match experimental measurements well [Stovall and Bogdan 2007].

One set of models focused not on foam aging, but on interior and exterior application factors, using publicly available codes, WUFI and THERM [Lohonyai, Korany, and Ross 2012]. This effort examined the influence of foam density for three possible foam applications to concrete masonry walls. 


\section{Appendix A Bibliography of Research in Foam Aging}

Three tables in this appendix summarize research since 2002, applications of closed-cell foam insulation, and research pre-2002. Complete citations are found in the references.

\section{Table 1 Post-2002 Research}

\begin{tabular}{|c|c|}
\hline $\begin{array}{l}\text { Polyurethane: Use WUFI for hygrothermal } \\
\text { and THERM for thermal performance, } \\
\text { initial performance only, no aging. } \\
\text { Compare interior vs. exterior applications } \\
\text { and two foam densities, University of } \\
\text { Alberta, Canada }\end{array}$ & $\begin{array}{l}\text { Lohonyai, Korany and Ross. 2012. Effective } \\
\text { Foam Insulation For Single-Wythe Concrete } \\
\text { Masonry Walls }\end{array}$ \\
\hline $\begin{array}{l}2^{\text {nd }} \mathrm{C} 1303 \text { ruggedness test (slice origin, } \\
\text { slice thickness, homogeneity screening } \\
\text { tests, accuracy compared to 5-year full } \\
\text { thickness aging) }\end{array}$ & $\begin{array}{l}\text { Stovall, Vanderlan, and Atchley. } 2012 . \\
\text { Evaluation of Experimental Parameters in the } \\
\text { Accelerated Aging of Closed-Cell Foam } \\
\text { Insulation } \\
\text { Stovall. 2009. Measuring the Impact of } \\
\text { Experimental Parameters upon the Estimated } \\
\text { Thermal Conductivity of Closed-Cell Foam } \\
\text { Insulation Subjected to an Accelerated Aging } \\
\text { Protocol: Two-Year Results } \\
\text { Stovall and Bogdan. 2007. Measuring the Impact } \\
\text { of Experimental Parameters upon the Estimated } \\
\text { Thermal Conductivity of Closed-Cell Foam } \\
\text { Insulation Subjected to an Accelerated Aging } \\
\text { Protocol }\end{array}$ \\
\hline $\begin{array}{l}\text { Compares thin slice aging to } 180 \text { days at } \\
23 \mathrm{C} \text { and to } 90 \text { days at } 60 \mathrm{C} \text { for spray foam } \\
\text { from } 25 \text { to } 75 \mathrm{~mm} \text { thick. }\end{array}$ & $\begin{array}{l}\text { Yuan. 2010. Thermal Conductivity of Spray } \\
\text { Polyurethane Foam Insulation Materials }\end{array}$ \\
\hline $\begin{array}{l}\text { Foam field-aged for } 6 \text { years. Impermeably- } \\
\text { faced products also aged significantly. }\end{array}$ & $\begin{array}{l}\text { Mukhopadhyaya, et al. } 2010 \text { In-Situ Long-term } \\
\text { Thermal Performance of Impermeably faced } \\
\text { Polyiso Foam Boards }\end{array}$ \\
\hline $\begin{array}{l}\text { Combines model and empirical data to } \\
\text { evaluate bias for thin slicing test methods } \\
\text { for two materials }\end{array}$ & $\begin{array}{l}\text { Singh and Coleman. 2007. Accelerated Aging } \\
\text { Test Methods for Predicting the Long Term } \\
\text { Thermal Resistance of Closed-Cell Foam } \\
\text { Insulation }\end{array}$ \\
\hline $\begin{array}{l}\text { Final report on } 1^{\text {st }} \mathrm{C} 1303 \text { ruggedness test } \\
\text { (TDSL) }\end{array}$ & $\begin{array}{l}\text { Stovall. 2006. Interlaboratory Comparison of the } \\
\text { Thickness of the Destroyed Surface Layer of } \\
\text { Closed-cell Foam Insulation Specimens }\end{array}$ \\
\hline
\end{tabular}




\begin{tabular}{|l|l|}
\hline $\begin{array}{l}\text { Compares rated R-values based on 2001 } \\
\text { version of CAN/ULC-S770 to full } \\
\text { thickness at ages }<5 \text { years, finds R-values } \\
\text { overstated with that test method. }\end{array}$ & $\begin{array}{l}\text { Graham. 2006. Testing LTTR, Research Reveals } \\
\text { the LTTR Method May Be Over-Reporting } \\
\text { Results }\end{array}$ \\
\hline $\begin{array}{l}\text { Important observations and measured data } \\
\text { showing impact of blowing agent } \\
\text { condensation on foam effectiveness (R- } \\
\text { Value) at lower temperatures. }\end{array}$ & $\begin{array}{l}\text { Bogdan, Hoerter, and Moore. 2005. Meeting the } \\
\text { Insulation Requirements of the Building } \\
\text { Envelope with Polyurethane and } \\
\text { Polyisocyanurate Foam }\end{array}$ \\
\hline $\begin{array}{l}\text { Compare 25 weeks at 70C to model result, } \\
\text { supports approach described in EN13165, } \\
\text { Annex C - European standard, new in } \\
\text { 2003 }\end{array}$ & $\begin{array}{l}\text { Dedecker, Baes and Singh. 2003. The } \\
\text { Measurement of 'Aged Thermal Conductivity' } \\
\text { of Factory Produced Insulation Boards }\end{array}$ \\
\hline $\begin{array}{l}\text { Model validation: 1) compare test method } \\
\text { (S770) to model, 2) compare model to } \\
\text { boards aged in lab }\end{array}$ & $\begin{array}{l}\text { Singh, Ntiru, and Dedecker. 2003. Long Term } \\
\text { Thermal Resistance of Pentane Blown } \\
\text { Polyisocyanurate Laminate Boards }\end{array}$ \\
\hline $\begin{array}{l}\text { Extending thin-slice methodology to } \\
\text { impermeably faced products, initial results } \\
\text { in a long-term project }\end{array}$ & $\begin{array}{l}\text { Mukhopadhyaya et al. 2002. Long-term Thermal } \\
\text { Resistance of Polyisocyanurate Foam Insulation } \\
\text { with Impermeable Facers }\end{array}$ \\
\hline $\begin{array}{l}\text { Compared results for versions of S770 and } \\
\text { C1303 in use in 2002 }\end{array}$ & $\begin{array}{l}\text { Stovall, Fabian, Nelson, and Beatty. 2002. A } \\
\text { Comparison of Accelerated Aging Test } \\
\text { Protocols for Cellular Foam Insulation }\end{array}$ \\
\hline
\end{tabular}

\section{Table 2 Foam Insulation Applications}

\begin{tabular}{|l|l|}
\hline $\begin{array}{l}\text { Important observations and measured data } \\
\text { showing impact of blowing agent } \\
\text { condensation on foam effectiveness (R-Value) } \\
\text { at lower temperatures. }\end{array}$ & $\begin{array}{l}\text { Bogdan, Hoerter, and Moore. 2005. Meeting } \\
\text { the Insulation Requirements of the building } \\
\text { Envelope with Polyurethane and } \\
\text { Polyisocyanurate Foam }\end{array}$ \\
\hline $\begin{array}{l}\text { Compares rated R-values based on 2001 } \\
\text { version of CAN/ULC-S770 to full thickness at } \\
\text { ages }<5 \text { years, finds R-values overstated with } \\
\text { that test method. }\end{array}$ & $\begin{array}{l}\text { Graham. 2006. Testing LTTR, Research } \\
\text { Reveals the LTTR Method May Be Over- } \\
\text { Reporting Results }\end{array}$ \\
\hline $\begin{array}{l}\text { Considers both energy performance during } \\
\text { lifetime service and lifetime emissions, finds } \\
\text { new CFC alternatives will have a reduction in } \\
\text { global warming. }\end{array}$ & $\begin{array}{l}\text { Fischer, Fairchild, and Hughes. 1992. Energy } \\
\text { and Global Warming Impacts of CFC } \\
\text { Alternative Technologies for Foam Building } \\
\text { Insulations }\end{array}$ \\
\hline $\begin{array}{l}\text { Final Report of an expert working group to } \\
\text { establish long-term R-values for foam } \\
\text { insulation products available at that time. }\end{array}$ & $\begin{array}{l}\text { Kabayama. 1987. Long-Term Thermal } \\
\text { Resistance Values of Cellular Plastic } \\
\text { Insulations }\end{array}$ \\
\hline
\end{tabular}




\begin{tabular}{|c|c|}
\hline $\begin{array}{l}\text { Comparing impact on foam aging of: }(1) \\
\text { plastic and steel sheet facing materials, }(2) \\
\text { alternative blowing agents, and ( } 3 \text { ) a range of } \\
\text { aging temperatures. Finding: the time required } \\
\text { for a given change in thermal conductivity } \\
\text { with aging at } 40 \mathrm{~F} \text { was roughly twice as long } \\
\text { as for aging at } 90 \mathrm{~F} \text {, while the time required at } \\
-10 \mathrm{~F} \text { was about } 10 \text { times as long as at } 90 \mathrm{~F} \text {. } \\
\text { Impact of plastic confinement was similar to } \\
\text { that projected using measured diffusion } \\
\text { coefficients. }\end{array}$ & $\begin{array}{l}\text { Wilkes, Yarbrough, and Weaver. 1997. Aging } \\
\text { of Polyurethane Foam Insulation in Simulated } \\
\text { Refrigerator Walls, } \\
\text { Wilkes, Yarbrough, Gabbard, Nelson, and } \\
\text { Booth. 2001. Aging of Polyurethane Foam } \\
\text { Insulation in Simulated Refrigerator Panels - } \\
\text { Three-Year Results with Third-generation } \\
\text { Blowing Agents } \\
\text { Wilkes, Yarbrough, Nelson, and Booth, } 2003 . \\
\text { Aging of Polyurethane Foam Insulation in } \\
\text { Simulated Refrigerator Panels - Four-Year } \\
\text { Results with Third-generation Blowing } \\
\text { Agents }\end{array}$ \\
\hline $\begin{array}{l}\text { Overview of what was known in } 1993 \text {, } \\
\text { including measured data for field exposed } \\
\text { materials. }\end{array}$ & $\begin{array}{l}\text { Bomberg and Alumbaugh. 1993. Factors } \\
\text { Affecting the Field Performance of Spray } \\
\text { Applied Thermal Insulating Foams }\end{array}$ \\
\hline $\begin{array}{l}\text { Foam field-aged for } 6 \text { years. Impermeably- } \\
\text { faced products also aged significantly. }\end{array}$ & $\begin{array}{l}\text { Mukhopadhyaya, et al. } 2010 \text { In-Situ Long- } \\
\text { term Thermal Performance of Impermeably } \\
\text { faced Polyiso Foam Boards }\end{array}$ \\
\hline $\begin{array}{l}\text { Early work comparing thin slices aged at } \\
\text { multiple temperatures to full thickness foam } \\
\text { aged in a roof exposed to the exterior } \\
\text { environment. Also showed early work to } \\
\text { derive diffusion coefficients from aging } \\
\text { thermal conductivity data. }\end{array}$ & $\begin{array}{l}\text { Christian, et al. 1991. Thermal Measurement } \\
\text { Of In-Situ And Thin-Specimen Ageing Of } \\
\text { Experimental Polyisocyanurate Roof } \\
\text { Insulation Foamed With Alternative Blowing } \\
\text { Agents }\end{array}$ \\
\hline $\begin{array}{l}\text { 10mm thin slice predictions matched field- } \\
\text { exposed HCFC-141b blown polyisocyanurate } \\
\text { within } 3 \%\end{array}$ & $\begin{array}{l}\text { Desjarlais, Christian, and Graves. 1993. In- } \\
\text { Situ Aging of Roof Systems Containing } \\
\text { Polyisocyanurate Roof Insulation Foamed } \\
\text { with Alternative Blowing Agents }\end{array}$ \\
\hline Foam chemistry related to fire retardants & $\begin{array}{l}\text { Singh, et al. 2006. Effect of Formulation } \\
\text { Parameters on Performance of } \\
\text { Polyisocyanurate Laminate Boardstock } \\
\text { Insulation, API } 2006\end{array}$ \\
\hline $\begin{array}{l}\text { Exterior foundation application - EPS only - } \\
\text { no deterioration after } 30 \text { months in situ - no } \\
\text { aging involved }\end{array}$ & $\begin{array}{l}\text { Swinton et al. 1999. In Situ Performance of } \\
\text { Expanded Molded Polystyrene in the Exterior } \\
\text { Basement Insulation Systems (EIBS) }\end{array}$ \\
\hline
\end{tabular}




\begin{tabular}{|l|l|}
\hline $\begin{array}{l}\text { Exterior foundation application - spray } \\
\text { polyurethane only - no deterioration after 30 } \\
\text { months in situ - "The aging process is slowed } \\
\text { because the polyurethane foam was sprayed } \\
\text { on dry surface of old concrete. In principle, } \\
\text { one may consider that the 76-mm thick } \\
\text { medium density SPF is exposed to one-sided } \\
\text { aging only." }\end{array}$ & $\begin{array}{l}\text { Swinton, et al. 2006 In Situ Performance } \\
\text { Evaluation Of Spray Polyurethane Foam In } \\
\text { (EIBS) }\end{array}$ \\
\hline $\begin{array}{l}\text { Interesting work, 1 inch boards aged for 1 } \\
\text { year in various environments. }\end{array}$ & $\begin{array}{l}\text { Zarr and Nguyen. 1994. Effects of Humidity } \\
\text { and Elevated Temperature on the Density and } \\
\text { Thermal Conductivity of a Rigid } \\
\text { Polyisocyanurate Foam Co-Blown with } \\
\text { CCl3F and CO2 }\end{array}$ \\
\hline $\begin{array}{l}\text { Compare n-pentane blown polyisocyanurate } \\
\text { to HCFC-141b boards. Lower initial thermal } \\
\text { conductivity offset by slower aging and } \\
\text { smaller cell sizes. }\end{array}$ & $\begin{array}{l}\text { Letts, et al. 2003. Insulation Boards Bridge to } \\
\text { the 21 }\end{array}$ \\
\hline $\begin{array}{l}\text { Polyurethane: Use WUtury } \\
\text { and THERM for thermal performance, initial } \\
\text { performance only, no aging. Compare interior } \\
\text { vs. exterior applications and two foam } \\
\text { densities, University of Alberta, Canada }\end{array}$ & $\begin{array}{l}\text { Fohonyai, Korany and Ross. 2012. Effective } \\
\text { Masonry Walls }\end{array}$ \\
\hline $\begin{array}{l}\text { Compares metal foils to polymeric facings, } \\
\text { aged 1-in. thick boards for 600 days. }\end{array}$ & $\begin{array}{l}\text { Soukup and Laughlin. 1991. Development of } \\
\text { an All-Purpose Impermeably-Faced Roof } \\
\text { Insulation }\end{array}$ \\
\hline
\end{tabular}

\section{Table 3 Pre-2002 Research}

Comprehensive work $-1^{\text {st }} /$ Best reference: Chapter 5, Heat transfer in foams," by Leon Glicksman and Chapter 6, "Thermal ageing," by C. J. Hoogendoorn. See especially 139-143 describing influence of foam properties on overall conductance
Glicksman. 1994. Heat Transfer in Foams

Hoogendoorn. 1994. Thermal Ageing

\section{MIT - GLICKSMAN:}

Focus on theoretical basis for models, experimental techniques re barrier adhesion

Early comparison of theoretical models to experimental data, pointing the need for better radiation models and better gas diffusion data.

Reviews fundamental relationships between foam morphology and conductive and radiative heat transfer through foam.
Valenzuela and Glicksman. 1983. Thermal Resistance and Aging of Rigid Urethane Foam Insulation

Schuetz and Glicksman, 1984, A Basic Study of Heat Transfer Through Foam Insulation 


\begin{tabular}{|c|c|}
\hline $\begin{array}{l}\text { Broad research program spanning } \\
\text { measurements of polymer properties, guarded } \\
\text { hot plate measurements at low temperatures } \\
\text { under vacuum to eliminate radiation and gas } \\
\text { transport, diffusion measurements, dye } \\
\text { techniques to expose inadequate foam-barrier } \\
\text { bonds }\end{array}$ & $\begin{array}{l}\text { Glicksman, Ostrogorsky and Chiapetta. } 1984 . \\
\text { Effective Conductivity of Aging Polyurethane } \\
\text { Foam, }\end{array}$ \\
\hline $\begin{array}{l}\text { Using measured foam diffusion coefficients, } \\
\text { presents the equations used in a numerical } \\
\text { solution for foam aging, with benchmarks } \\
\text { shown to full thickness aging out to } \sim \text { two } \\
\text { years. Shows most foam surface barriers have } \\
\text { little effect on aging. Emphasizes the } \\
\text { advantages of thin slicing over elevated } \\
\text { temperature acceleration methods. }\end{array}$ & $\begin{array}{l}\text { Glicksman and Page. 1992. Long-Term } \\
\text { Performance of Closed-Cell Foam Insulation } \\
\text { Ostrogorsky and Glicksman. 1989. Time } \\
\text { Variation of Insulating Properties of Closed } \\
\text { Cell Foam Insulation } \\
\text { Ostrogorsky. 1985. Ageing of polyurethane } \\
\text { foams }\end{array}$ \\
\hline $\begin{array}{l}\text { Proposes a test method to quantify the barrier } \\
\text { performance }\end{array}$ & $\begin{array}{l}\text { Glicksman 1994. The Role of Barriers in } \\
\text { Reducing the Aging of Foam Panels }\end{array}$ \\
\hline \multicolumn{2}{|c|}{$\begin{array}{l}\text { CANADA - BOMBERG, KUMARAN: } \\
\text { Focus on thin-slicing vs. elevated temperature, support development of CAN/ULC-S770, spray } \\
\text { foam }\end{array}$} \\
\hline $\begin{array}{l}\text { Final Report of an expert working group to } \\
\text { establish long-term R-values for foam } \\
\text { insulation products available at that time. }\end{array}$ & $\begin{array}{l}\text { Kabayama. 1987. Long-Term Thermal } \\
\text { Resistance Values of Cellular Plastic } \\
\text { Insulations }\end{array}$ \\
\hline $\begin{array}{l}\text { Important observations and measured data } \\
\text { showing impact of blowing agent condensation } \\
\text { on foam effectiveness (R-Value) at lower } \\
\text { temperatures. }\end{array}$ & $\begin{array}{l}\text { Kumaran, et al. 1989. A Method for } \\
\text { Evaluating the Effect of Blowing Agent } \\
\text { Condensation on Sprayed Polyurethane Foams }\end{array}$ \\
\hline $\begin{array}{l}\text { Overview of the state of knowledge regarding } \\
\text { thin slice aging acceleration in } 1989 .\end{array}$ & $\begin{array}{l}\text { Edgecombe. 1989. Progress in Evaluating } \\
\text { Long-Term Thermal Resistance Of Cellular } \\
\text { Plastics }\end{array}$ \\
\hline $\begin{array}{l}\text { Early work applying thin-slicing methodology } \\
\text { to spray foam. }\end{array}$ & $\begin{array}{l}\text { Bomberg and Kumaran. 1989. Report on } \\
\text { Sprayed Polyurethane Foam with Alternative } \\
\text { Blowing Agents }\end{array}$ \\
\hline $\begin{array}{l}\text { Detailed explanation re the measurement of } \\
\text { TDSL }\end{array}$ & $\begin{array}{l}\text { Schwartz, Bomberg and Kumaran. } 1989 . \\
\text { Measurements Of The Rate Of Gas Diffusion } \\
\text { In Rigid Cellular Plastics }\end{array}$ \\
\hline $\begin{array}{l}\text { Overview - interesting reference to } \\
\text { experimental work that shows impact of } \\
\text { temperature on aging (where/why might get } \\
\text { useful data). }\end{array}$ & $\begin{array}{l}\text { Bomberg and Gilbo. 1989. Introduction to } \\
\text { Aging of Cellular Plastics }\end{array}$ \\
\hline
\end{tabular}




\begin{tabular}{|c|c|}
\hline $\begin{array}{l}\text { Shows performance after } 2 \text { years unaffected by } \\
\text { periods of elevated temperature up to } 7 \\
\text { months. Also examines influence of } \\
\text { differences between diffusion resistance in } \\
\text { surface and core regions. }\end{array}$ & $\begin{array}{l}\text { Bomberg. 1990. Scaling factors in ageing of } \\
\text { gas-filled cellular plastics }\end{array}$ \\
\hline $\begin{array}{l}\text { Use of thin-slice accelerated aging to evaluate } \\
\text { potential blowing agent substitutions. }\end{array}$ & $\begin{array}{l}\text { Kumaran and Bomberg. 1990. Thermal } \\
\text { Performance Of Sprayed Polyurethane Foam } \\
\text { Insulation With Alternative Blowing Agents. }\end{array}$ \\
\hline $\begin{array}{l}\text { Overview of the state of knowledge regarding } \\
\text { thin slice aging acceleration in } 1989 \text {. ALSO, } \\
\text { reviews broad range of uncertainty for C518 } \\
\text { results for all insulation materials at that time. }\end{array}$ & $\begin{array}{l}\text { Bomberg and Brandreth. 1990. Evaluation Of } \\
\text { Long-Term Thermal Resistance Of Gas-Filled } \\
\text { Foams: State Of The Art }\end{array}$ \\
\hline $\begin{array}{l}\text { Review of pre-1991 research re accelerated } \\
\text { aging, both heat and thin-slicing, and } \\
\text { description of future research needs }\end{array}$ & $\begin{array}{l}\text { Bomberg and Kumaran, 1991. Evaluation of } \\
\text { Long-Term Thermal Performance of Cellular } \\
\text { Plastics Revisited }\end{array}$ \\
\hline $\begin{array}{l}\text { Editorial work providing discussion of field } \\
\text { performance vs. lab measurements with } \\
\text { anecdotal evidence for both fibrous and foam } \\
\text { products }\end{array}$ & $\begin{array}{l}\text { Bomberg. 1993. The Evolution of Insulation } \\
\text { Research }\end{array}$ \\
\hline $\begin{array}{l}\text { Interesting 3-way comparison between thin- } \\
\text { slice predictions and full thickness aging, both } \\
\text { in the field and in the laboratory. Laboratory } \\
\text { and field aging agreed within } \sim 1 \% \text {. Thin-slice } \\
\text { predictions agreed with full thickness aging } \\
\text { within } \sim 6 \%\end{array}$ & $\begin{array}{l}\text { Bomberg. 1993. Predicting Field Thermal } \\
\text { Performance of a Modified Resol Foam from } \\
\text { Laboratory Data }\end{array}$ \\
\hline $\begin{array}{l}\text { Overview of what was known in } 1993 \text {, } \\
\text { including measured data for field exposed } \\
\text { materials. }\end{array}$ & $\begin{array}{l}\text { Bomberg and Alumbaugh. 1993. Factors } \\
\text { Affecting the Field Performance of Spray } \\
\text { Applied Thermal Insulating Foams }\end{array}$ \\
\hline \multirow[t]{2}{*}{$\begin{array}{l}\text { Describes significant experience with thin- } \\
\text { slicing spray polyurethane and need for quality } \\
\text { assurance processes for new spray products. }\end{array}$} & $\begin{array}{l}\text { Bomberg and Kumaran. 1994. Testing Long- } \\
\text { Term Thermal Resistance of Sprayed } \\
\text { Polyurethane Foam, }\end{array}$ \\
\hline & $\begin{array}{l}\text { Bomberg M.T. and M.K. Kumaran, 1994, } \\
\text { Laboratory And Roofing Exposures Of } \\
\text { Cellular Plastic Insulation To Verify A Model } \\
\text { Of Aging }\end{array}$ \\
\hline $\begin{array}{l}\text { Demonstrated ability of multiple labs to } \\
\text { perform the thin slicing procedure, but with } \\
\text { variations of } 7 \text { to } 25 \% \text { of the predicted LTTR } \\
\text { between labs. }\end{array}$ & $\begin{array}{l}\text { Hofton. 2001. Standard For Determination Of } \\
\text { Long-Term Thermal Resistance (LTTR) Of } \\
\text { Closed Cell Thermal Insulating Foams, } \\
\text { CAN/ULC-S770-99 Round Robin Test } \\
\text { Programme }\end{array}$ \\
\hline
\end{tabular}




\begin{tabular}{|c|c|}
\hline \multicolumn{2}{|c|}{ EUROPE } \\
\hline $\begin{array}{l}\text { Early work to differentiate between the } \\
\text { conductive and radiative heat transfer through } \\
\text { foam }\end{array}$ & $\begin{array}{l}\text { Jones. 1967. The Effect of Thickness and } \\
\text { Temperature on Heat Transfer through Foam } \\
\text { Polymers }\end{array}$ \\
\hline $\begin{array}{l}\text { Compares different methods used to rate foam } \\
\text { insulation thermal conductivity at that time and } \\
\text { recommends a common practice for Nordic } \\
\text { countries based on } 10 \text { mm slices measured } \\
\text { after } 3 \text { months. This research covers all the } \\
\text { major factors addressed during research } \\
\text { between } 1988 \text { and } 2012 \text {, except for the } \\
\text { influence of blowing agents not in use at that } \\
\text { time. It recommends that measurements taken } \\
\text { at } 90 \text { days for } 10 \mathrm{~mm} \text { slices are accurate } \\
\text { predictions for } 25 y \text { year-aged products }+-5 \% \text { for } \\
\text { PUR (CFCl3) of } 20-200 \mathrm{~mm} \text { thickness and for } \\
\text { XPS (CF2C12) of } 50-200 \mathrm{~mm} \text { thickness ( } 30 \\
\text { mm if the surface skin is retained). }\end{array}$ & $\begin{array}{l}\text { Isberg, J. 1988. Thermal Insulation-- } \\
\text { Conditioning of Rigid Cellular Plastics } \\
\text { Containing a Gas with Lower Thermal } \\
\text { Conductivity Than Air Prior to Determination } \\
\text { of Thermal Resistance and Related Properties }\end{array}$ \\
\hline $\begin{array}{l}\text { Good early work on thin slicing, discusses } \\
\text { general theory and potential error sources }\end{array}$ & $\begin{array}{l}\text { Sandberg, P. I. and J. Isberg, Measurement of } \\
\text { Aged Thermal Resistance of Rigid Gas-Filled } \\
\text { Cellular Plastics, J of Thermal Insulation, V13, } \\
\text { Oct } 1989\end{array}$ \\
\hline $\begin{array}{l}\text { Considering use of } \mathrm{CO}_{2} \text { as an alternative } \\
\text { blowing agent. Includes an excellent } \\
\text { description of the Wassiljewa equation for the } \\
\text { thermal conductivity of gas mixtures. }\end{array}$ & $\begin{array}{l}\text { Smits and Thoen. 1991. Fundamental Aspects } \\
\text { of Thermal Conductivity Aging and } \\
\text { Dimensional Stability of Rigid Polyurethane } \\
\text { Foams }\end{array}$ \\
\hline $\begin{array}{l}\text { Describes work including } 15 \text { years of full } \\
\text { thickness aging for polyurethane boards } \\
\text { (possibly concluded in 1998, so boards } \\
\text { manufactured in 1983?). Also describes test } \\
\text { results for impact of water absorption and other } \\
\text { influences. }\end{array}$ & $\begin{array}{l}\text { BING, Federation of European Rigid } \\
\text { Polyurethane Foam Associations. } 2006 . \\
\text { Thermal Insulation materials Made of Rigid } \\
\text { Polyurethane Foam (PUR/PIR) }\end{array}$ \\
\hline $\mathrm{PhD}$ thesis & $\begin{array}{l}\text { Svanstrom, M., 1997, Blowing Agents in Rigid } \\
\text { Polyurethane Foam }\end{array}$ \\
\hline $\begin{array}{l}\text { Compares results from } 90 \text { day elevated } \\
\text { temperature thin-slice accelerated aging } \\
\text { methods, pointing out that a correction factor is } \\
\text { needed for the } 90 \text { day approach but not for the } \\
\text { thin slice approach. }\end{array}$ & $\begin{array}{l}\text { Sandberg. 1990. Deterioration of Thermal } \\
\text { Insulation Properties of Extruded Polystyrene: } \\
\text { Classification and Quality Control System in } \\
\text { Sweden }\end{array}$ \\
\hline
\end{tabular}


OAK RIDGE NATIONAL LABORATORY:

Focus on thin-slice aging, full thickness field exposure

Uses a fully coupled conductive and radiative algorithm to explore interactions between the measurement device and the specimen that impact the measured value of thermal conductivity.

Aging full thickness boards 3 years in the lab and installed as foundation insulation - show long term average $\mathrm{R}$-value $\sim 7-10 \%$ less than the 180 -day value

Early thin slicing work on PIR boardstock, comparing thermal conductivity measurement apparatus, impact of slice thickness and aging temperature, applying models developed at ORNL and MIT

Examining the early heat flow meter apparatus and influence of their accuracy on thin-slice method

Early work comparing thin slices aged at multiple temperatures to full thickness foam aged in a roof exposed to the exterior environment. Also showed early work to derive diffusion coefficients from aging thermal conductivity data.

$10 \mathrm{~mm}$ thin slice predictions matched fieldexposed HCFC-141b blown polyisocyanurate within $3 \%$

Compares thin slice predictions to field-aged boards in multiple roof types over 3.4 years.

Tested slice thicknesses as small as $0.6 \mathrm{~mm}$, using measured TDSL to correct measured values for thermal resistance.

Broad study done to support the development of ASTM C1303. Important findings regarding timing of thermal conductivity measurements.
Fine, et al. 1981. Heat Transfer In Building

Thermal Insulation: The Thickness Effect

Yarbrough, Graves, and Christian. 1991.

Thermal Performance of HCFC-22 Blown

Extruded Polystyrene Insulation

McElroy et al., 1991, Laboratory Test Results on the Thermal Resistance of Polyisocyanurate Foamboard Insulation Blown with CFC-11

Substitutes - a Cooperative

Industry/Government Project

Graves, et al. 1991. Interlaboratory comparison of four heat flow meter apparatuses on planed polyisocyanurate boards foamed with CFC-11

Christian, et al. 1991. Thermal Measurement Of In-Situ And Thin-Specimen Ageing Of Experimental Polyisocyanurate Roof Insulation Foamed With Alternative Blowing Agents

Desjarlais, Christian, and Graves. 1993. In-Situ Aging of Roof Systems Containing Polyisocyanurate Roof Insulation Foamed with Alternative Blowing Agents

Christian et al. 1993. The Technical Viability of Alternative Blowing Agents in Polyisocyanurate Roof Insulation: A Cooperative Industry/Government Project

Booth, Graves, and Yarbrough. 1995. Aging of Thin-Slices of PIR Foams Manufactured with Alternative Blowing Agents

Graves et al. 1995. Interlaboratory comparison on Estimating the Long-Term Thermal Resistance of Unfaced, Rigid, Closed-Cell, Polyisocyanurate (PIR) Foam Insulation - A Cooperative Industry/Government Project 


\begin{tabular}{|c|c|}
\hline $\begin{array}{l}\text { Compares thin slice predictions to field-aged } \\
\text { boards in multiple roof types over } 5 \text { years, } \\
\text { showing they matched within } 1.5 \% \text {. Multiple } \\
\text { slice thicknesses were used in the comparison. }\end{array}$ & $\begin{array}{l}\text { Christian, et al. 1995. Five-Year Field Study } \\
\text { Confirms the PIMA Standard for Estimating } \\
\text { Polyisocyanurate Insulation Long-Term } \\
\text { Thermal Performance }\end{array}$ \\
\hline $\begin{array}{l}\text { Using thin slices, shows variation from } 30 \text { to } \\
40 \% \text { for diffusion coefficients measured } \\
\text { gravimetrically to those measured using } \\
\text { thermal conductivity. Discusses practical } \\
\text { limitations to method. }\end{array}$ & $\begin{array}{l}\text { Booth, Graves, and Yarbrough. 1996. Effective } \\
\text { Diffusion Coefficients for CFC-11 by } \\
\text { Gravimetric Depletion from Thin Slices of PIR } \\
\text { Foam }\end{array}$ \\
\hline \multicolumn{2}{|c|}{ OTHER U.S. LABORATORIES } \\
\hline $\begin{array}{l}\text { Focus is on the difference between rated/label } \\
\text { values for thermal resistance and the changes } \\
\text { that occur under multiple aging conditions for } \\
\text { the first } 2 \text { years. }\end{array}$ & $\begin{array}{l}\text { Desjarlais and Tye, 1987, Experimental } \\
\text { Methods for Determining the Thermal } \\
\text { Performance of Cellular Plastic Insulation } \\
\text { Materials Used in Roofs }\end{array}$ \\
\hline boards aged for 1 year & $\begin{array}{l}\text { Zarr and Nguyen. 1994. Effects of Humidity } \\
\text { and Elevated Temperature on the Density and } \\
\text { Thermal Conductivity of a Rigid } \\
\text { Polyisocyanurate Foam Co-Blown with CCl3F } \\
\text { and CO2 }\end{array}$ \\
\hline \multicolumn{2}{|c|}{$\begin{array}{l}\text { INDUSTRY: } \\
\text { Focus on test method development to facilitate product improvements and product ratings }\end{array}$} \\
\hline $\begin{array}{l}\text { Comparison between two field aged PIR } \\
\text { specimens, one open cell and one closed cell, } \\
\text { over five year period. Compares measured } \\
\text { values to predicted values. }\end{array}$ & $\begin{array}{l}\text { Muhlenkamp and Johnson. 1983. In-Place } \\
\text { Thermal Aging of Polyurethane Foam Roof } \\
\text { Insulations }\end{array}$ \\
\hline $\begin{array}{l}\text { Points out problems associated with elevated } \\
\text { temperature aging, specifically cell rupture and } \\
\text { product swelling }\end{array}$ & $\begin{array}{l}\text { Booth, and Drouin. 1989. R-Value Aging of } \\
\text { Rigid Foam Insulation Products }\end{array}$ \\
\hline $\begin{array}{l}\text { Multiple papers re heat aging, thin slice aging, } \\
\text { gas diffusion rates, differences between core } \\
\text { and surface slices }\end{array}$ & $\begin{array}{l}\text { SPI. 1989. Proceedings 1st Int. Workshop } \\
\text { Long-Term Thermal Performance of Cellular } \\
\text { Plastics, Canada } \\
\text { Some papers reproduced in J of Thermal } \\
\text { Insulation V13, April } 1990\end{array}$ \\
\hline $\begin{array}{l}\text { Collation of manufacturers' data in } 1990 \text { with } \\
\text { emphasis on aging and variation with } \\
\text { temperature }\end{array}$ & $\begin{array}{l}\text { Strzepek, W.R., 1990, Overview of Physical } \\
\text { Properties of Cellular Thermal Insulations }\end{array}$ \\
\hline $\begin{array}{l}\text { Compares full thickness aging after } 11 \text { years to } \\
\text { full thickness aging after } 5 \text { years for foil-faced } \\
\text { PIR products. }\end{array}$ & $\begin{array}{l}\text { Hagan and Miller. 1990. Long-Term R-Values } \\
\text { and Thermal Testing Requirements for Rigid } \\
\text { Insulating Foams }\end{array}$ \\
\hline
\end{tabular}




\begin{tabular}{|c|c|}
\hline $\begin{array}{l}\text { Describes apparatus and analysis along with } \\
\text { measured values for multiple gases in multiple } \\
\text { foam specimens. }\end{array}$ & $\begin{array}{l}\text { Shankland. 1990. Measurement of Gas } \\
\text { Diffusion in Closed-Cell Foams }\end{array}$ \\
\hline $\begin{array}{l}\text { Major focus on extracting diffusion } \\
\text { coefficients from thermal conductivity data. }\end{array}$ & $\begin{array}{l}\text { Booth. 1991. Some factors affecting the long- } \\
\text { term thermal insulating performance of } \\
\text { extruded polystyrene foams, insulation } \\
\text { materials, testing and applications. }\end{array}$ \\
\hline $\begin{array}{l}\text { Used slices with up to } 8 \% \text { TDSL, Corrections } \\
\text { made to all results. }\end{array}$ & $\begin{array}{l}\text { Booth and Grimes. 1993. Comparison of Full- } \\
\text { Board and Thin-Slice Aging of XEPS } \\
\text { Manufactured with Alternative Blowing Agent }\end{array}$ \\
\hline $\begin{array}{l}\text { Describes physics used in Dow model and } \\
\text { compares results to full-thickness measured } \\
\text { data, describes relationship to quality assurance } \\
\text { measurements that can be made immediately } \\
\text { after foam manufacture }\end{array}$ & $\begin{array}{l}\text { Booth. 1993. An Evaluation of the Dow } \\
\text { Thermal Performance Prediction Model for a } \\
\text { Database of XEPS/CRD-12 Aged Resistivity } \\
\text { and Physical Properties }\end{array}$ \\
\hline $\begin{array}{l}\text { Gas diffusion rates, finding limits re small slice } \\
\text { thicknesses }\end{array}$ & $\begin{array}{l}\text { Bhattacharjee, D. P.W. Irwin, J.R. Booth, J.T. } \\
\text { Grimes, The Acceleration of Foam Aging by } \\
\text { Thin-Slicing: Some Interpretations and } \\
\text { Limitations, J. Thermal Insul. And Bldg. } \\
\text { Envs., Vol 17, Jan } 1994\end{array}$ \\
\hline $\begin{array}{l}\text { Early interlaboratory comparison of C1303 test } \\
\text { method found good agreement between } \\
\text { laboratories with different slicing techniques, } \\
\text { but later analysis was the basis for eliminating } \\
\text { hot-wire cutting from the test method. }\end{array}$ & $\begin{array}{l}\text { Fabian, et al. 1997. A Variability Study on the } \\
\text { ASTM Thin Slicing and Scaling Test Method } \\
\text { for Evaluating the Long[-term Performance of } \\
\text { an Extruded Polystyrene Foam Blown with } \\
\text { HCFC-142b }\end{array}$ \\
\hline $\begin{array}{l}\text { Compares a standard analytical solution for a } \\
\text { single gas to the results of their numerical } \\
\text { procedure before producing multi-gas results. }\end{array}$ & $\begin{array}{l}\text { Kondapi, Booth and Yarbrough. } 1999 . \\
\text { Transient Gas Diffusion in Closed-Cell Foam } \\
\text { Using an Implicit Finite Difference Method }\end{array}$ \\
\hline $\begin{array}{l}\text { Reviews LTTRs per CAN/ULC-S770-00 for } \\
\text { pentane-blown PIR foams from three } \\
\text { manufacturers. }\end{array}$ & $\begin{array}{l}\text { Laughlin, et al. 2003. Insulation Boards Bridge } \\
\text { to the } 21^{\text {st }} \text { Century }\end{array}$ \\
\hline
\end{tabular}




\section{Appendix B. Standards That Use Long-Term Aging, And Standard Test Methods}

\begin{tabular}{|c|c|}
\hline $\begin{array}{l}\text { EN 13164, November 2008, ICS } \\
\text { 91.100.60, Thermal insulation products for } \\
\text { buildings - Factory made products of } \\
\text { extruded polystyrene foam (XPS) - } \\
\text { Specification } \\
\text { EN 14307, November 2009, Thermal } \\
\text { insulation products for building equipment } \\
\text { and industrial installations - Factory made } \\
\text { extruded polystyrene foam (XPS) products } \\
\text { - Specification }\end{array}$ & $\begin{array}{l}\text { Annex C: } \\
\text { Thin slice aging, } 10 \mathrm{~mm}(+-1 \mathrm{~mm}) \text {, slices taken } \\
\text { from throughout the product profile. Number of } \\
\text { days ( } 30 \text { to } 90) \text { specified for product thicknesses } \\
\text { from } 120 \text { to } 20 \mathrm{~mm} \text {. Correction for TDSL added. } \\
\text { If foil faced, store full-thickness board for } 60 \\
\text { days at } 23 \mathrm{C} \text {, then measure. }\end{array}$ \\
\hline $\begin{array}{l}\text { EN 13165, November 2008, Thermal } \\
\text { insulation products for buildings - Factory } \\
\text { made rigid polyurethane foam (PUR) } \\
\text { products - Specification } \\
\text { EN 14308, November 2009, Thermal } \\
\text { insulation products for building equipment } \\
\text { and industrial installations - Factory made } \\
\text { rigid polyurethane foam (PUR) and } \\
\text { polyisocyanurate foam (PIR) products - } \\
\text { Specification } \\
\text { EN 14315-1:2011, Thermal insulating } \\
\text { products for buildings - In-situ formed } \\
\text { sprayed rigid polyurethane (PUR) and } \\
\text { polyisocyanurate (PIR) foam products - } \\
\text { Part 1: Specification for the rigid foam } \\
\text { spray system before installation } \\
\text { EN 14318-1:2011, Thermal insulating } \\
\text { products for buildings - In-situ formed } \\
\text { dispensed rigid polyurethane (PUR) and } \\
\text { polyisocyanurate (PIR) foam products - } \\
\text { Part 1: Specification for the rigid foam } \\
\text { dispensed system before installation }\end{array}$ & $\begin{array}{l}\text { Annex C: } \\
\text { Option 1: } 175 \text { days at } 70 \mathrm{C} \text { with safety increments. } \\
\text { Safety increments can be modified based on } \\
\text { comparison between } 23 \text { and } 70 \mathrm{C} \text { aged values. } \\
\text { Option 2: Add fixed increment to initial thermal } \\
\text { conductivity if pass test based on } 21 \text { days at } 70 \mathrm{C} \text {. }\end{array}$ \\
\hline
\end{tabular}




\begin{tabular}{|c|c|}
\hline $\begin{array}{l}\text { EN 14315-2:2011, Thermal insulating } \\
\text { products for buildings - In-situ formed } \\
\text { sprayed rigid polyurethane (PUR) and } \\
\text { polyisocyanurate (PIR) foam products - } \\
\text { Part 2: Specification for the installed } \\
\text { insulation products } \\
\text { EN 14318-2:2011, CEN/TC } 88 \text { Secretariat: } \\
\text { DIN, Thermal insulating products for } \\
\text { buildings - In-situ formed dispensed rigid } \\
\text { polyurethane (PUR) and polyisocyanurate } \\
\text { (PIR) foam products - Part 2: } \\
\text { Specification for the installed insulation } \\
\text { products }\end{array}$ & $\begin{array}{l}\text { Companion documents for the specifications (Part } \\
\text { 1), reference those specifications, except that EN } \\
\text { ISO6946 can be used for complete building } \\
\text { elements, corrections for moisture and } \\
\text { temperature per EN ISO } 10456 \text { may be added. }\end{array}$ \\
\hline $\begin{array}{l}\text { EN 13166, November } 2008 \text {, Thermal } \\
\text { insulation products for buildings - Factory } \\
\text { made products of phenolic foam (PF) - } \\
\text { Specification }\end{array}$ & $\begin{array}{l}\text { Annex C: } \\
\text { Thin slice aging, } 10 \mathrm{~mm}(+-1 \mathrm{~mm}) \text {, slices taken } \\
\text { from throughout the product profile. Number of } \\
\text { days }(30 \text { to } 90) \text { specified for product thicknesses } \\
\text { from } 120 \text { to } 20 \mathrm{~mm} \text {. Correction for TDSL added. } \\
\text { Option } 2: 175 \text { days at } 70 \mathrm{C} \text { or } 14 \text { days at } 110 \mathrm{C} \text {, } \\
\text { with correction factors }\end{array}$ \\
\hline $\begin{array}{l}\text { EN 14314, November 2009, Thermal } \\
\text { insulation products for building equipment } \\
\text { and industrial installations - Factory made } \\
\text { phenolic foam (PF) products - } \\
\text { Specification }\end{array}$ & $\begin{array}{l}\text { Annex B: } \\
175 \text { days at } 70 \mathrm{C} \text { or } 14 \text { days at } 110 \mathrm{C} \text {, with } \\
\text { correction factors }\end{array}$ \\
\hline $\begin{array}{l}\text { NORD (Swedish National Testing Institute, } \\
\text { Chalmers University of Technology, and } \\
\text { NRCC, Isberg, 1988) } \\
\text { ASTM C1303 Standard Test Method for } \\
\text { Predicting Long-Term Thermal Resistance } \\
\text { of Closed-Cell Foam Insulation } \\
\text { ISO 11561, 1999, Ageing of thermal } \\
\text { insulation materials - Determination of } \\
\text { the long-term change in thermal resistance } \\
\text { of closed-cell plastics (accelerated } \\
\text { laboratory test methods) } \\
\text { CAN/ULC S770, Standard for } \\
\text { Determination of Long-Term Thermal } \\
\text { Resistance of Closed Cell Thermal } \\
\text { Insulating Foams }\end{array}$ & $\begin{array}{l}\text { All based on thin-slicing per Fick's Law of } \\
\text { diffusion for homogenous materials } \\
\text { NORD: Uses } 10 \mathrm{~mm} \text { slices at } 91 \text { days to predict } \\
\text { the } 25 \text { year thermal conductivity of } 100 \mathrm{~mm} \\
\text { products. Uses a full cross section of the original } \\
\text { material. } \\
\text { S770: Uses separate core and surface slice results } \\
\text { at specified times to calculate the 5-year thermal } \\
\text { conductivity for full thickness products. Earlier } \\
\text { versions used the lowest aged thermal } \\
\text { conductivity of core or surface slice stacks. } \\
\text { Current version uses a combination of the two } \\
\text { results. } \\
\text { C1303: Offers prescriptive path, using predictions } \\
\text { for } 5 \text { years of age, or research path, using full } \\
\text { aging curve. }\end{array}$ \\
\hline
\end{tabular}




\begin{tabular}{|l|l|}
\hline $\begin{array}{l}\text { ISO 2440, 1997, Flexible and rigid cellular } \\
\text { Polymeric materials - Accelerated ageing } \\
\text { tests }\end{array}$ & $\begin{array}{l}\text { Heat and humidity conditions used to age for } \\
\text { compression or indentation hardness, not used for } \\
\text { thermal conductivity aging }\end{array}$ \\
\hline ACERMI - Association pour la \\
\hline Certification de Materiaux Isolants & $\begin{array}{l}\text { Maintains the foam at an elevated temperature } \\
\text { (70C) for a prescribed period of time (2 months). } \\
\text { This produces an accurate simulation of long- } \\
\text { term ( 20 years) aged value IF blowing agent } \\
\text { diffusion rate is }<<\text { diffusion rates for } \mathrm{N}_{2} \text { and } \mathrm{O}_{2} . \\
\text { However, for many new blowing agents, the } \\
\text { blowing agent diffusion rate is greater than it was } \\
\text { for CFC-11, so this test will instead produce } \\
\text { values representative of foam after 1-2 } \\
\text { years.[Hoogendoorn } 1994 \text { and Bomberg and } \\
\text { Gilbro 1989] }\end{array}$ \\
\hline $\begin{array}{l}\text { PIMA Technical Bulletin \#101, 180 Day } \\
\text { Impermeable Faced Procedyiso }\end{array}$ & $\begin{array}{l}180 \text { days at 23C, does not profess to represent } \\
\text { long-term average performance, rating purposes }\end{array}$ \\
\hline US Federal Specification HH-1-530A & 90 days at 60C \\
\hline $\begin{array}{l}\text { Canadian General Standards Board } \\
\text { (CGSB) }\end{array}$ & $\begin{array}{l}28 \text { days at 100C (problems with foam } \\
\text { dimensional stability, product thickness } \\
\text { increased) }\end{array}$ \\
\hline $\begin{array}{l}\text { US Federal Trade Commission "R-Value } \\
\text { Rule" }\end{array}$ & 6 months at 23C or 90 days at 60C \\
\hline
\end{tabular}




\section{REFERENCES}

ASTM. 2012. ASTM C1303 Standard Test Method for Predicting Long-Term Thermal Resistance of Closed-Cell Foam Insulation, Annual Book of ASTM Standards

Bhattacharjee, D. P., W. Irwin, J.R. Booth, and J.T. Grimes. 1994. "The Acceleration of Foam Aging by Thin-Slicing: Some Interpretations and Limitations,” J Thermal Insul. And Bldg. Envs., Vol 17, Jan.

Bogdan, M., J. Hoerter, and J.O. Moore. 2005. "Meeting the Insulation Requirements of the Building Envelope with Polyurethane and Polyisocyanurate Foam," J of Cellular Plastics, V41, P1, pp 41-56

Bomberg M.T., 1988. "A Model of Aging of Gas-Filled Cellular Plastics," J of Cellular Plastics, Vol. 24, No. 4, July, p. 327-347

Bomberg, M., and K. Kumaran. 1989. Report on Sprayed Polyurethane Foam with Alternative Blowing Agents, CFCs \& the Polyurethane Industry: A Compilation of Technical Publications, Vol. 2 (F.W. Lichtenburg, ed.), Technomic Publishing Co.,1988-1989

Bomberg, M., and C. Gilbo. 1989. "Introduction to Aging of Cellular Plastics," J of Thermal Insulation, V13, October

Booth, R. J. and M. P. Drouin. 1989. "R-Value Aging of Rigid Foam Insulation Products,” J of Thermal Insulation, V 13, October

Bomberg, M.T. 1990. "Scaling factors in ageing of gas-filled cellular plastics," J of Thermal Insulation, 13, January, p. 149.

Bomberg, M.T. and D.A. Brandreth. 1990. "Evaluation of long-term thermal resistance of gasfilled foams: State of the art, insulation materials, testing and applications," Insulation Materials Testing and Applications, ASTM STP 1030, D.L. McElroy and J.F. Kimpflen, eds., American Society for Testing and Materials, Philadelphia, pp. 156-173.

Bomberg M.T. and M.K. Kumaran. 1991. "Evaluation of Long-Term Thermal Performance of Cellular Plastics Revisited," ASTM STP 1116, (R.S. Graves and D.C. Wysocki, eds.), American Society for Testing and Materials, Philadelphia, 1991, pp 123-141

Bomberg, M. and R.L. Alumbaugh. 1993. "Factors Affecting the Field Performance of Spray Applied Thermal Insulating Foams," Spray Foam '93, Orlando FL, Society of the Plastics Industry, Inc., Washington DC, Feb.

Bomberg, M. 1993. "Predicting Field Thermal Performance of a Modified Resol Foam from Laboratory Data,” J. Thermal Insul. And Bldg. Envs., Vol 17, July, pp 78-88

Bomberg, M. 1993. "The Evolution of Insulation Research,”, J Thermal Insul. And Bldg. Envs., Vol 16, Jan., pp 227-229

Bomberg, M. and K. Kumaran. 1994. “Testing Long-Term Thermal Resistance of Sprayed Polyurethane Foam,” J Thermal Insul. And Bldg. Envs., Vol 17, Jan., pp 283-291

Bomberg M.T. and M.K. Kumaran,.1994. "Laboratory And Roofing Exposures Of Cellular Plastic Insulation To Verify A Model Of Aging”, Roofing Research and Standards Development, 
ASTM STP 1224, T. J. Wallace and W. J. Rossiter, Jr., Eds., American Society for Testing and Materials, Philadelphia

BING, Federation of European Rigid Polyurethane Foam Associations. 2006. Thermal Insulation materials Made of Rigid Polyurethane Foam (PUR/PIR), Report No 1, October

Bomberg M.T., Y.S. Muzychka, D.G. Stevens, and M.K. Kumaran. 1994. "A Comparative Test Method To Determine Thermal Resistance Under Field Conditions," J. Thermal Insul. and Bldg. Envs., Vol 18, Oct., pp 163-181

Booth, J.R. 1991. "Some factors affecting the long-term thermal insulating performance of extruded polystyrene foams, insulation materials, testing and applications," ASTM STP 1116, R.S. Graves and D.C. Wysocki, eds., American Society for Testing and Materials, Philadelphia, pp. 197-213.

Booth, J.R. and J.T. Grimes. 1993. "Comparison of Full-Board and Thin-Slice Aging of XEPS Manufactured with Alternative Blowing Agent,” J. Thermal Insul and Bldg. Envs., V16 April

Booth, J.R. 1993. "An Evaluation of the Dow Thermal Performance Prediction Model for a Database of XEPS/CRD-12 Aged Resistivity and Physical Properties,” J. Thermal Insul. And Bldg. Envs., Vol 17, Oct. pp 154-170

Booth, J.R., R.S. Graves, and D.W. Yarbrough. 1995. "Aging of Thin-Slices of PIR Foams Manufactured with Alternative Blowing Agents," J. Thermal Insul. and Bldgs. Envs. V19, Oct.

Booth, J.R., R. S. Graves, and D. W. Yarbrough. 1996. "Effective Diffusion Coefficients for CFC-11 by Gravimetric Depletion from Thin Slices of PIR Foam," Proceedings of the TwentyThird Internation Thermal Conductivity Conference, Eds. K.W. Wilkes, R.B. Dinwiddie, and R.S. Graves, pp 325-337

Childs, K.W. 1993. HEATING 7.2 User's Manual, ORNL/TM-12262, Oak Ridge National Laboratory, Oak Ridge, Tennessee

Christian, J.E., G.E. Courville, R.S. Graves, R.L. Linkous, D.L. McElroy, F.J. Weaver and, D.W. Yarbrough. 1991. "Thermal Measurement Of In-Situ And Thin-Specimen Ageing Of Experimental Polyisocyanurate Roof Insulation Foamed With Alternative Blowing Agents," Insulation Materials, Testing And Applications, ASTM STP 1116, R.S. Graves and D.C. Wysocki, eds., American Society for Testing and Materials, Philadelphia, pp. 142-166.

Christian, J.E., G.E. Courville, A.O. Desjarlais, R.S. Graves, R.L. Linkous, D.L., McElroy, F.J. Weaver, R.L. Wendt, and, D.W. Yarbrough. 1993. The Technical Viability of Alternative Blowing Agents in Polyisocyanurate Roof Insulation: A Cooperative Industry/Government Project, ORNL/CON-367, June

Christian, J.E., A.O. Desjarlais, R.S. Graves, and T.L. Smith. 1995. "Five-Year Field Study Confirms the PIMA Standard for Estimating Polyisocyanurate Insulation Long-Term Thermal Performance," Proceedings of the 11th Conference on Roofing Technology, Gaithersburg, MD, September

Cuddihy, E.F. and and J. Moacanin. 1967. "Diffusion of Gases in Ploymeric Foams," J Cellular Plastics, 3, 73.

Dedecker, K., M. Baes and S. N. Singh. 2003. "The Measurement of 'Aged Thermal Conductivity' of Factory Produced Insulation Boards," Utech 2003 
Desjarlais, A.O. and R.P.Tye. 1987. "Experimental Methods for Determining the Thermal Performance of Cellular Plastic Insulation Materials Used in Roofs," Eighty Conference on Roofing Technology, Gaithersburg, MD, April 16-17, National Roofing Contractors Association

Desjarlais, A.O., J.E. Christian, and R.S. Graves. 1993. "In-Situ Aging of Roof Systems Containing Polyisocyanurate Roof Insulation Foamed with Alternative Blowing Agents," 3rd International Workshop on Long-Term Thermal Performance of Cellular Plastics, Toronto, Canada, October

Edgecombe, F.H. 1989. "Progress in Evaluating Long-Term Thermal Resistance Of Cellular Plastics," CFCS \& Polyurethane Industry: A Compilation of Technical Publications, Vol. 2, F.W. Lichtenburg, ed., Technomic Publishing Co., pp. 17-24. (also found in Proceedings of SPI 32nd Annual Technical/Marketing conference, 1989)

Fabian, B.A., R.S. Graves, M.R. Hofton and D.W. Yarbrough. 1997. "A Variability Study on the ASTM Thin Slicing and Scaling Test Method for Evaluating the Long-Term Performance of an Extruded Polystyrene Foam Blown with HCFC-142b," Insulation Materials: Testing and Applications: Third Volume, ASTM STP 1320, R.S. Graves and R.R. Zarr, Eds., ASTM, 1997

Fine, H.A., S.H. Jury, D.W. Yarbrough, and D.L. McElroy. 1981. "Heat Transfer In Building Thermal Insulation: The Thickness Effect," ASHRAE Transactions, CONF-810657, V 87, pp. 89-107, Jun.

Fischer, S.K., P.D. Fairchild, and P.J. Hughes. 1992. "Energy and Global Warming Impacts of CFC Alterntive Technologies for Foam Building Insulations," Proceedings of the Thermal Performance of the Exterior Envelopes of Buildings V, December 7-10, ASHRAE, Atlanta, GA, pp 74-80

Glicksman, L. R., A.G. Ostrogorsky and S. Chiapetta. 1984. Effective Conductivity of Aging Polyurethane Foam, ORNL/SUB/84-9009/1, Oak Ridge National Laboratory, Oak Ridge, TN, March

Glicksman, L.R. and M. Page. 1992. "Long-Term Performance of Closed-Cell Foam Insulation," Proceedings of the Thermal Performance of the Exterior Envelopes of Buildings V, December 710, ASHRAE, Atlanta, GA, pp 81-90

Glicksman, L.R. 1994. "Heat Transfer in Foams," Low Density Cellular Plastics Physical Basis of Behaviour, N. C. Hilyard and A. Cunningham, eds., Chapman \& Hall, London, pp. 104-152

Glicksman, L. R. 1994b. "The Role of Barriers in Reducing the Aging of Foam Panels," J. Thermal Insul. And Bldg. Envs. Vol 17, January, pp. 249-266

Graham, M.S. 2006. "Testing LTTR, Research Reveals the LTTR Method May Be OverReporting Results,” Professional Roofing Magazine, Jan.

Graves, R.S., D.L. McElroy, R.G. Miller, D.W. Yarbrough and R.R. Zarr. 1991. Interlaboratory Comparison Of Four Heat Flow Meter Apparatuses On Planed Polyisocyanurate Boards Foamed With CFC-11, Oak Ridge National Laboratory Report ORNL/TM-11720, January.

Graves, R.S., D.L., McElroy, F.J. Weaver, and D.W. Yarbrough. 1995. Interlaboratory Comparison on Estimating the Long-Term Thermal Resistance of Unfaced, Rigid, Closed-Cell, Polyisocyanurate (PIR) Foam Insulation - A Cooperative Industry/Government Project, Oak Ridge National Laboratory Report ORNL/M-3976, January 
Hagan, J.R. and R. G. Miller. 1990. "Long-Term R-Values and Thermal Testing Requirements for Rigid Insulating Foams," Insulation Materials Testing and Applications, ASTM STP 1030, D.L. McElroy and J.F. Kimpflen, eds., American Society for Testing and Materials, Philadelphia Hofton, M. 2001. Standard For Determination Of Long-Term Thermal Resistance (LTTR) Of Closed Cell Thermal Insulating Foams, CAN/ULC-S770-99 Round Robin Test Program

Hoogendoorn, C.J. 1994. "Thermal Ageing”, Low Density Cellular Plastics Physical Basis of Behaviour, N.C. Hilyard and A. Cunningham, eds., Chapman \& Hall, London, pp. 153-186

Isberg, J. 1988. Thermal Insulation - Conditioning of Rigid Cellular Plastics Containing a Gas with Lower Thermal Conductivity Than Air Prior to Determination of Thermal Resistance and Related Properties, NORDTEST Project No 603-86, Chalmers University of Technology, Goteborg, Sweden, Dec. (translated by L.J. Gruber)

Jones, T.T. 1967. "The Effect of Thickness and Temperature on Heat Transfer through Foam Polymers," Thermal Conductivity, Proceedings of the Seventh Conference, Gaithersburg, MD, November

Kabayama, M.A. 1987. "Long-Term Thermal Resistance Values of Cellular Plastic Insulations," J. Thermal Insul. And Bldg. Envs., Vol 10, Apr., pp. 286-300

Kondapi, P. B., J.R. Booth and D.W. Yarbrough. 1999. "Transient Gas Diffusion in Closed-Cell Foam Using an Implicit Finite Difference Method,” Thermal Conductivity 24, Technomic Publishing Company, pp. 428-436

Kumaran, M.K. and M.T. Bomberg. 1990. "Thermal Performance Of Sprayed Polyurethane Foam Insulation With Alternative Blowing Agents," Journal of Thermal Insulation, 14, July, pp. 43-58.

Kumaran, M.K., M.T. Bomberg, R.G. Marchand, J.A. Creazzo, and M.R. Ascough. 1989. “A Method for Evaluating the Effect of Blowing Agent Condensation on Sprayed Polyurethane Foams, "CFCS \& Polyurethane Industry: A Compilation of Technical Publications, Vol. 2 (F.W. Lichtenburg, ed.), Technomic Publishing Co., 1988-1989

Laughlin, W.E., J.B. Letts, M.K. Ntiru and S.N.Singh. 2003. "Insulation Boards Bridge to the $21^{\text {st }}$ Century," Professional Roofing, January, pp 22-27

Letts, J. B., W. E. Laughlin, S. N. Singh and M. K. Ntiru. 2003. "Insulation Boards Bridge to the 21st Century," Professional Roofing, January

Lindsay, A.L. and L. A. Bromley. 1950. "Thermal Conductivity of Gas Mixtures,” Ind. and Eng. Chem., 42(8), pp. 1508-1511.

Lohonyai, A.J., Y. Korany and M.D. Ross. 2012. "Effective Foam Insulation For Single-Wythe Concrete Masonry Walls," Journal of Building Physics published online 22 October

McElroy, D.L., R.S. Graves, D.W. Yarbrough, and F.J. Weaver. 1991. Laboratory Test Results on the Thermal Resistance of Polyisocyanurate Foamboard Insulation Blown with CFC-11 Substitutes - a Cooperative Industry/Government Project, ORNL/TM-11645, Oak Ridge National Laboratory, Oak Ridge, TN, September. 
Muhlenkamp, S.P. and S.E. Johnson. 1983. "In-Place Thermal Aging of Ployurethane Foam Roof Insulations," Paper No. 11, Seventh Conference on Roofing Technology, Gaithersburg, April 14-15, National Roofing Contractors Association

Mukhopadhyaya, P., M. Drouin, N. Normandin, D. VanReenen, J. Lackey, 2010. “In-Situ LongTerm Thermal Performance of Impermeably faced Polyiso Foam Boards," International Conference on Building Envelope Systems and Technologies (ICBEST) 2010, Proceedings Ed. By A. Baskaran

Mukhopadhyaya, P., M.T. Bomberg, M.K. Kumaran, M. Drouin, J. Lackey, D. VanReenen, and N. Normandin. 2002. "Long-term Thermal Resistance of Polyisocyanurate Foam Insulation with Impermeable Facers," published as NRCC-45216 and in Insulation Materials: Testing and Applications: 4th Volume, ASTM STP 1426, A.O. Desjarlais, Ed., West Conshohocken, PA, pp. 351-365

Mukhopadhyaya, P., M.T. Bomberg, M.K. Kumaran, M. Drouin, J. Lackey, D. VanReenen, and N. Normandin. 2004. "Long-Term Thermal Resistance of Polyisocyanurate Foam Insulation with Gas Barrier," Performance of Exterior Envelopes of Whole Buildings IX International Conference, ASHRAE, December

Norton, F.J. 1967. "Thermal Conductivity and Life of Polymer Foams," J. Cellular Plastics, 3, 23.

Ostrogorsky, A.G. 1985. Ageing of polyurethane foams, D.Sc. Thesis, Massachusetts Institute of Technology, Cambridge, MA.

Ostrogorsky, A.G. and L. R. Glicksman. 1986. Aging of Polyurethane Foams, The Influence of Gas Diffusion on Thermal Conductivity, ORNL/SUB/84-9009/2, Oak Ridge National Laboratory, Oak Ridge, TN, August

Ostrogorsky, A.G. and L. R. Glicksman. 1989. "Time Variation of Insulating Properties of Closed Cell Foam Insulation," J of Thermal Insulation, V 12, April, pp. 270-283; also published in Insulation Materials Testing and Applications, ASTM STP 1030, D.L. McElroy and J.F. Kimpflen, eds., American Society for Testing and Materials, Philadelphia, 1990

Sandberg, P. I. and J. Isberg. 1989. "Measurement of Aged Thermal Resistance of Rigid GasFilled Cellular Plastics," J of Thermal Insulation, V 13, Oct

Sandberg, P.I. 1990. "Deterioration of Thermal Insulation Properties of Extruded Polystyrene: Classification and Quality Control System in Sweden," Insulation Materials Testing and Applications, ASTM STP 1030, D.L. McElroy and J.F. Kimpflen, eds., American Society for Testing and Materials, Philadelphia

Schuetz, M.A. and L.R. Glicksman. 1984. "A Basic Study of Heat Transfer Through Foam Insulation," Journal of Cellular Plastics, Vol 20(2), March-April, pp 114-121

Schwartz, N.V., M.T. Bomberg and M.K. Kumaran. 1989. "Measurements Of The Rate Of Gas Diffusion In Rigid Cellular Plastics,” Journal of Thermal Insulation, V. 13, pp. 48-61.

Shankland, I.R. 1990. "Measurement of Gas Diffusion in Closed-Cell Foams," Insulation Materials Testing and Applications, ASTM STP 1030, D.L. McElroy and J.F. Kimpflen, eds., American Society for Testing and Materials, Philadelphia 
Singh, S. N, M. Ntiru, and K. Dedecker. 2002. "Long Term Thermal Resistance of Pentane Blown Polyisocyanurate Lamiate Boards," API in 2002, also in Journal of Cellular Plastics, Vol 39, N 4, pp 265-280, July 2003

Singh, S. N, J. S. Fife, S. Dubs, P. D. Coleman. 2006. "Effect of Formulation Parameters on Performance of Polyisocyanurate Laminate Boardstock Insulation," API 2006

Singh, S. N., and P. D. Coleman. 2007. "Accelerated Aging Test Methods for Predicting the Long Term Thermal Resistance of Closed-Cell Foam Insulation," CPI 2007, Orlando, FL

Smits, G.F. and J.A. Thoen. 1991. "Fundamental Aspects of Thermal Conductivity Aging and Dimensional Stability of rigid Polyurethane Foams," ASTM STP 1116, R.S. Graves and D.C. Wysocki, eds., American Society for Testing and Materials, Philadelphia, pp 167-193

Soukup, T.G. and W.E. Laughlin. 1991. "Development of an All-Purpose Impermeably-Faed Roof Insulation," Polyurethanes World Congress - September 24-26

SPI. 1989. Proceedings 1st Int. Workshop Long-Term Thermal Performance of Cellular Plastics, Canada

Stovall, T.K., B.A., Fabian, G.E. Nelson, and D.R., Beatty. 2002. "A Comparison of Accelerated Aging Test Protocols for Cellular Foam Insulation," Insulation Materials: Testing and Applications: 4th Volume, ASTM STP 1426, A. O. Desjarlais and R. R. Zarr, Eds., American Society for Testing and Materials, West Conshohocken, PA.

Stovall, T.K. 2006. "Interlaboratory Comparison of the Thickness of the Destroyed Surface Layer of Closed-Cell Foam Insulation Specimens," Presented at ASTM Symposium on HeatAir-Moisture Transport: Measurements on Building Materials on 23-26 April 2006 in Toronto, Canada; P. Mukhopadhyaya and M. Kumaran, Guest Editors, Journal of ASTM International, Vol. 4, No 1, December

Stovall, T.K. and M. Bogdan. 2008. "Measuring the Impact of Experimental Parameters upon the Estimated Thermal Conductivity of Closed-Cell Foam Insulation Subjected to an Accelerated Aging Protocol," Thermal Conductivity 29/Thermal Expansion 17, Joint Conferences, June 2427, 2007, Birmingham, AL, J. R. Koenig and H. Ban, Eds., DEStech Publications, Inc., Lancaster, PA

Stovall, T.K. 2009. "Measuring the Impact of Experimental Parameters upon the Estimated Thermal Conductivity of Closed-Cell Foam Insulation Subjected to an Accelerated Aging Protocol: Two-Year Results," Journal of ASTM International, Vol. 6, No. 5, Paper ID JAI102025, April (also in ASTM STP 1519)

Stovall, T.K., M. Vanderlan, and J.A. Atchley. 2012. Evaluation of Experimental Parameters in the Accelerated Aging of Closed-Cell Foam Insulation, ORNL/TM-2012/214. December

Strzepek, W.R. 1990. "Overview of Physical Properties of Cellular Thermal Insulations," Insulation Materials Testing and Applications, ASTM STP 1030, D.L. McElroy and J.F. Kimpflen, eds., American Society for Testing and Materials, Philadelphia

Svanstrom, M. 1997. "Blowing Agents in Rigid Polyurethane Foam," Ph.D. Thesis, Chalmers University of Technology, Goteborg, Sweden. 
Swinton ,M.C., M.T. Bomberg, M.K. Kumaran and W. Mareff. 1999. "In Situ Performance of Expanded Molded Polystyrene in the Exterior Basement Insulation Systems (EIBS)," Journal of Building Physics, (previously J. Thermal Env. \& Bldg. Sci.) V 23: pp. 173-198

Swinton, M.C., W. Maref, M.T. Bomberg, M.K., Kumaran and N. Normandin. 2006. In Situ Performance Evaluation Of Spray Polyurethane Foam In The Exterior Insulation Basement System (EIBS), NRCC-47312, A version of this document is published in Building and Environment, v. 41, no. 12, Dec. 2006, pp. 1872-1880.

Underwriters Laboratory of Canada, S770 CAN/ULC, Standard for Determination of Long-Term Thermal Resistance of Closed Cell Thermal Insulating Foams, 333 Pfingsten Road, Northbrook, IL

Valenzuela, J.A., and, L.R. Glicksman. 1983. "Thermal Resistance and Aging of Rigid Urethane Foam Insulation," Thermal Insulation, Materials, and Systems for Energy Conservation in the '80s, ASTM STP 789, F.A. Govan, D.M. Greason, and J.D. McAllister, Eds., ASTM, pp. 688702

Wang,J.K. and C.E. Hagentoft. 1998. "A Simplified Model for Aging of Gas-filled Thermal Insulating Foams" J. Thermal Envelope and Building Science, Vol. 22, October.

Wang, J.K., and C.E. Hagentoft. 1999. "An Algorithm to Accelerate Simulations of Simultaneous Heat and Gas Transfer in Gas-Filled Foams," J of Building Physics 22: 230

Wassiljewa, A.1904. "Warmeleitung in Gasgemischen," Physikalishe Zeitschrift, 5(22), pp. 737 742

Wilkes, K.E., D.W. Yarbrough, and F.J. Weaver. 1997. “Aging of Polyurethane Foam Insulation in Simulated Refrigerator Walls," International Conference on Ozone Protection Technologies, pp. 253-262.

Wilkes, K.E., D.W. Yarbrough, W.A. Gabbard, G. E. Nelson, and J.R. Booth. 2001. “Aging of PolyurethaneFoamInsulationinSimulatedRefrigeratorPanels-Three-YearResultswithThirdgenerationBlowing Agents," Polyurethanes Expo 2001, pp. 313-324

Wilkes, K.E., A.O. Desjarlais, T.K. Stovall, D.L. McElroy, K.W. Childs, and W.A. Miller. 2002. "A Pipe Insulation Test Apparatus for Use Below Room Temperature," Insulation Materials: Testing and Applications; $4^{\text {th }}$ Volume, ASTM STP 1426, A.O. Desjarlais and R.R. Zarr, Eds., ASTM International, West Conshohocken, PA.

Wilkes, K.E., D.W. Yarbrough, G.E. Nelson, and J.R. Booth. 2003. “Aging of Polyurethane Foam Insulation in Simulated Refrigerator Panels - Four-Year Results with Third-generation Blowing Agents," The Earth Technologies Forum, April 22-24.

Yuan, S., 2010. "Thermal Conductivity of Spray Polyurethane Foam Insulation Materials," Thermal Conductivity 30 /Thermal Expansion 18, Joint Conferences, Aug. 9-Sept. 2, 2009, Pittsburgh, PA, D.S. Gaal and P.S. Gaal, Eds., DEStech Publications, Inc., Lancaster, PA

Yarbrough, D.W., R.S. Graves, and J.E. Christian. 1991. "Thermal Performance of HCFC-22 Blown Extruded Polystyrene Insulation," Insulation Materials: Testing and Applications, 2nd Volume, ASTM STP1116, R.S. Graves and D.C. Wysocki, Eds., ASTM, Philadelphia 
Zarr, R. R. and T. Nguyen. 1994. "Effects of Humidity and Elevated Temperature on the Density and Thermal Conductivity of a Rigid Polyisocyanurate Foam Co-Blown with CC13F and CO2," J. Thermal Insul. And Bldg. Envs, V 17, April 